Research article

\title{
Three new species of Euphorbia subgenus Chamaesyce (Euphorbiaceae) endemic to Brazil
}

\author{
Otávio Luis Marques da SILVA ${ }^{1, *}$, Pierre BRAUN ${ }^{2}$, Ricarda RIINA ${ }^{3}$ \& Inês CORDEIRO ${ }^{4}$ \\ ${ }^{1,4}$ Instituto de Botânica, Secretaria de Infraestrutura e Meio Ambiente, Cx. Postal 3005, \\ 01061-970, São Paulo, SP, Brazil. \\ ${ }^{2}$ Im Fusstal 37, D-50171 Kerpen, Germany. \\ ${ }^{3}$ Real Jardín Botánico, RJB-CSIC, Plaza de Murillo 2, Madrid, 28014, Spain. \\ "Corresponding author: otaviolmarques@gmail.com \\ ${ }^{2}$ Email: pbraunger@aol.com \\ 33Email: rgriina@gmail.com \\ Email: isandona@uol.com.br \\ 1 ๑ https://orcid.org/0000-0002-4561-5936 \\ 2 (1) https://orcid.org/0000-0002-2558-284X \\ 3 ○ https://orcid.org/0000-0002-7423-899X \\ 4 ๑ https://orcid.org/0000-0002-2626-5280
}

\begin{abstract}
We describe and illustrate three new species of Euphorbia subgenus Chamaesyce from Brazil: E. blepharadena O.L.M.Silva \& Cordeiro sp. nov., E. longipedunculata O.L.M.Silva \& Riina sp. nov. and E. sobolifera O.L.M.Silva \& P.J.Braun sp. nov. Based on morphological characteristics, E. blepharadena $\mathrm{sp}$. nov. and E. longipedunculata sp. nov. are placed in the subcosmopolitan section Anisophyllum, whereas E. sobolifera sp. nov. is placed in the more geographically restricted section Crossadenia. The three new species are compared with their most similar species in each section, and accompanied by comments on habitat and distribution, illustrations, photographs, and proposed conservation status.
\end{abstract}

Keywords. Euphorbia section Crossadenia, Euphorbia section Anisophyllum, caatinga, cerrado, Neotropics, taxonomy.

Silva O.L.M., Braun P., Riina R. \& Cordeiro I. 2021. Three new species of Euphorbia subgenus Chamaesyce (Euphorbiaceae) endemic to Brazil. European Journal of Taxonomy 733: 72-86.

https://doi.org/10.5852/ejt.2021.733.1223

\section{Introduction}

Euphorbia L. includes more than 2000 species, which makes it the most diverse genus of Euphorbiaceae Juss., and one of the largest within the angiosperms (Govaerts et al. 2000; Horn et al. 2012; Webster 2014). Despite its great variation in morphology, ranging from small annual plants to large and longlived trees, the genus is characterized by a synapomorphy, unique among angiosperms, the cyathium 
(Horn et al. 2012). This pseudanthial inflorescence consists of a cup-like involucre with glands along its rim (sometimes with appendages of several types) enclosing a single, central pistillate flower surrounded by four or five staminate cymules with reduced axes. Both the pistillate and staminate flowers are highly reduced to a single pistil and a single stamen, respectively (Radcliffe-Smith 2001; Prenner \& Rudall 2007; Horn et al. 2012; Webster 2014), and in some species with unisexual cyathia, pistillate or staminate flowers may be reduced to a pistillode or staminodes (Rizzini 1989; Silva et al. 2020).

Phylogenetic studies have confirmed the monophyly of Euphorbia and recognized four subgenera: E. subg. Athymalus Neck. ex Rchb., restricted to the Old World (Peirson et al. 2013); E. subg. Esula Pers., mostly centered in temperate regions of the northern hemisphere (Riina et al. 2013); E. subg. Euphorbia, the most morphologically diverse, found mainly in the tropics and subtropics (Dorsey et al. 2013); and E. subg. Chamaesyce Raf., distributed primarily in the New World but also represented in the Old World (Yang et al. 2012).

Brazil is the most Euphorbia species-rich country in South America (Steinmann 2013). Currently, 64 native species of Euphorbia are recorded for Brazil, half of them endemic to the country (Flora do Brasil 2020, in construction). Since the last complete treatment of the genus for Brazil (the monograph in Flora Brasiliensis by Müller Argoviensis 1874), additional new species and new occurrences have been published, even in the past few years (Carrillo-Reyes \& Steinmann 2011; Carneiro-Torres et al. 2012; Silva \& Cordeiro 2015; Hurbath et al. 2018; Küllkamp et al. 2018; Silva et al. 2020).

Euphorbia subg. Chamaesyce is the most species-rich lineage of Euphorbia in Brazil, with two thirds of the species belonging to this subgenus. Within the subgenus, E. sect. Anisophyllum Roep. and E. sect. Crossadenia Boiss. are the most diverse sections, with 27 and 11 species, respectively (Flora do Brasil 2020, in construction; Silva et al. 2020). Based on extensive herbarium studies, we present and describe three new Brazilian species of Euphorbia subg. Chamaesyce, and, based on morphological evidence, we place two of them in E. sect. Anisophyllum and the third one in E. sect. Crossadenia.

\section{Material and methods}

We examined the collections of Euphorbia deposited in SP, SPF, HUEFS, MBM and RB; acronyms of herbaria follow Index Herbariorum (Thiers, continuously updated). Protologues and type specimens of related species were also analyzed through JSTOR Global Plants website (https://plants.jstor.org/). Morphological descriptions were based on observations using a 10-60× magnification stereo microscope. We followed Beentje (2010) for general terminology, and for cyathial features we applied the specific terms from the Euphorbia Planetary Biodiversity Inventory group (www.euphorbiaceae.org) and relevant systematic treatments for Euphorbia (Horn et al. 2012; Yang et al. 2012). The distribution map was generated in QGIS ver. 3.14 (QGIS Development Team 2020), and the conservation status was proposed based on the International Union for the Conservation of Nature guidelines (IUCN 2019), adopting area of occupancy with a cell width of $2 \mathrm{~km}$ in GeoCAT (available from geocat.kew.org/). 


\title{
Results
}

\author{
Class Magnoliopsida Brongn. \\ Order Malpighiales Mart. \\ Family Euphorbiaceae Juss. \\ Genus Euphorbia L.
}

Euphorbia blepharadena O.L.M.Silva \& Cordeiro sp. nov.

urn:lsid:ipni.org:names:77214813-1

Figs $1-2$

\section{Diagnosis}

Euphorbia blepharadena O.L.M.Silva \& Cordeiro sp. nov. is similar to Euphorbia foliolosa Boiss. but differs in its smaller leaves with a denser indumentum composed of long (ca $1 \mathrm{~mm}$ ) trichomes, cyathial glands with digitate appendages and pubescent ovary/fruit.

\section{Type}

BRAZIL • Minas Gerais, Jaíba, Furados, "lado direito da Estrada Jaíba - Mocambinho" [right side of the road Jaíba - Mocambinho]; 15²12'37" S, 4351'33" W; 19 Oct. 2001; J.A. Lombardi et al. 4433; holotype: UEC[018613]; isotype: BHCB[64825].

\section{Etymology}

The epithet is a reference to the cyathial gland appendages, which look like eyelashes on these glands (Fig. 1G).

\section{Description}

Erect monoecious herbs, up to $30 \mathrm{~cm}$ tall; underground system not seen; latex white. Stems terete, irregularly branched, brown when dried, pubescent, with short $(<0.25 \mathrm{~mm})$ curved and longer (ca $1 \mathrm{~mm})$ erect simple trichomes. Leaves opposite, persistent, subsessile (petioles reaching up to $1 \mathrm{~mm}$ long); stipules interpetiolar, deltoid, inconspicuous (up to $1 \mathrm{~mm}$ long), apex fimbriate, indumentum of erect, long (ca $1 \mathrm{~mm}$ ), simple trichomes; leaf blade membranaceous, pilose on the adaxial surface and densely pilose on the abaxial surface, both surfaces with erect, long (ca $1 \mathrm{~mm}$ ), simple trichomes, discolorous (abaxial surface slightly lighter), elliptic to oblong, $0.5-0.8(-1) \times 0.15-0.2 \mathrm{~cm}$, base asymmetric, margin serrate with a colleter at the apex of each tooth, apex acute, venation hyphodromous. Cyathia solitary, axillary, subsessile; peduncle up to $1.5 \mathrm{~mm}$ long, with a few scattered erect, long (ca $1 \mathrm{~mm}$ ), simple trichomes; involucre turbinate, $1.5-2.5 \times 0.8-1.3 \mathrm{~mm}$, actinomorphic, pilose on the outer surface, with erect, long (ca $1 \mathrm{~mm}$ ), simple trichomes; involucral lobes triangular, pale to greenish when dried, margin fimbriate; cyathial glands 4(5), dark when dried, transversely elliptic and slightly concave, smooth, glabrous, $0.2-0.3 \times 0.2-0.3 \mathrm{~mm}$; cyathial gland appendages 6-8-digitate, lobes linear, $1.5-1.8(-2) \mathrm{mm}$ long, white when dried, glabrous. Staminate flowers $25-35$, arranged in (4)5 cincinni with 6-7 flowers each; bracteoles lanceolate, ciliate; pedicels up to $2 \mathrm{~mm}$ long, filaments up to $1 \mathrm{~mm}$ long, anthers ca $0.5 \mathrm{~mm}$ wide, dorsifixed, extrorse, transversely dehiscent. Pistillate flowers ca $7 \mathrm{~mm}$ long; pedicel up to $2.5 \mathrm{~mm}$ long; ovary globose, ca $1.5 \times 1.5 \mathrm{~mm}$, densely pubescent, with erect, long (ca $1 \mathrm{~mm}$ ), simple trichomes; styles 3, 3.5-4 mm long, united only at the base, entire and slightly revolute at the apex, glabrous. Capsules 3-lobed, subglobose, 3.0-3.5 $\times 3.5-4 \mathrm{~mm}$, pubescent, with erect, long (ca $1 \mathrm{~mm}$ ) simple trichomes, green; pedicel shortly accrescent, reaching up to $4 \mathrm{~mm}$ long; columella $2-2.5 \mathrm{~mm}$ long; seeds brown, ovoid, ca $2 \times 1 \mathrm{~mm}$, tetragonous in cross section, testa shallowly tuberculate. 

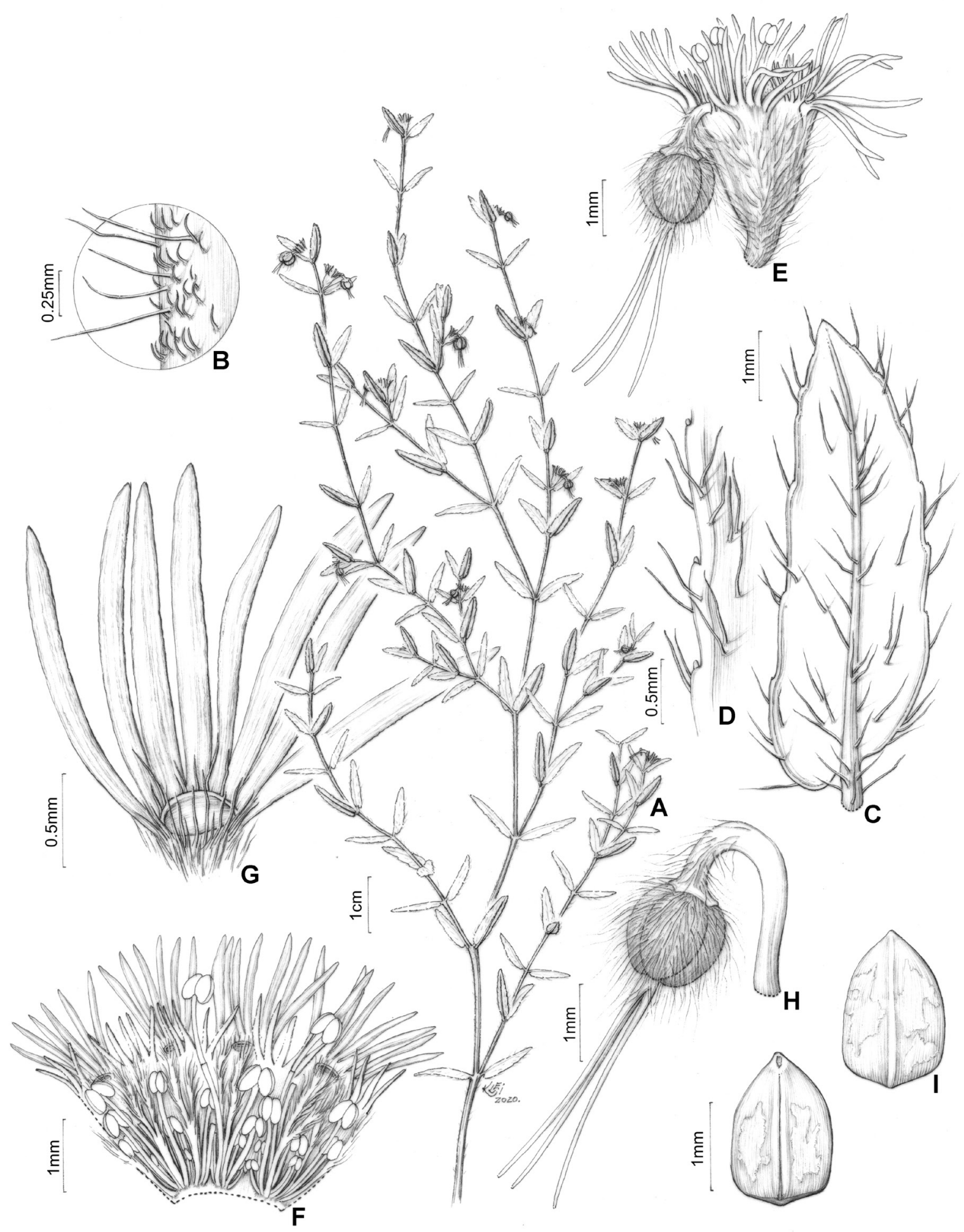

Fig. 1. Euphorbia blepharadena O.L.M.Silva \& Cordeiro sp. nov. A. Habit. B. Detail of indumentum on branches, with curved short and longer erect trichomes. C. Leaf. D. Detail of leaf blade margin, showing a colleter at the apex of each tooth. E. Cyathium. F. Opened cyathium, showing staminate cymules and bracteoles. G. Isolated cyathial gland, with its fimbriate appendage. H. Young fruit. I. Seeds in ventral (left) and dorsal (right) views. Illustration of the holotype, J.A. Lombardi et al. 4433 (UEC), by Klei Souza. 


\section{Distribution, ecology, and phenology}

Euphorbia blepharadena sp. nov. occurs in clay soils in flat rocky outcrops ('lageado') in northeast Minas Gerais, within the Cerrado domain (Fig. 2). The only specimen found so far was collected in October with both flowers and fruits.

\section{Provisional conservation status}

Euphorbia blepharadena sp. nov. is only known from a single locality (Fig. 2), with AOO $<10 \mathrm{~km}^{2}$ and $\mathrm{EOO}<100 \mathrm{~km}^{2}$. Its habitat is subjected to continuing decline in area, extent and quality. In the light of this, our evaluation suggests it to be classified as Critically Endangered (CR; B2ab[iii]).

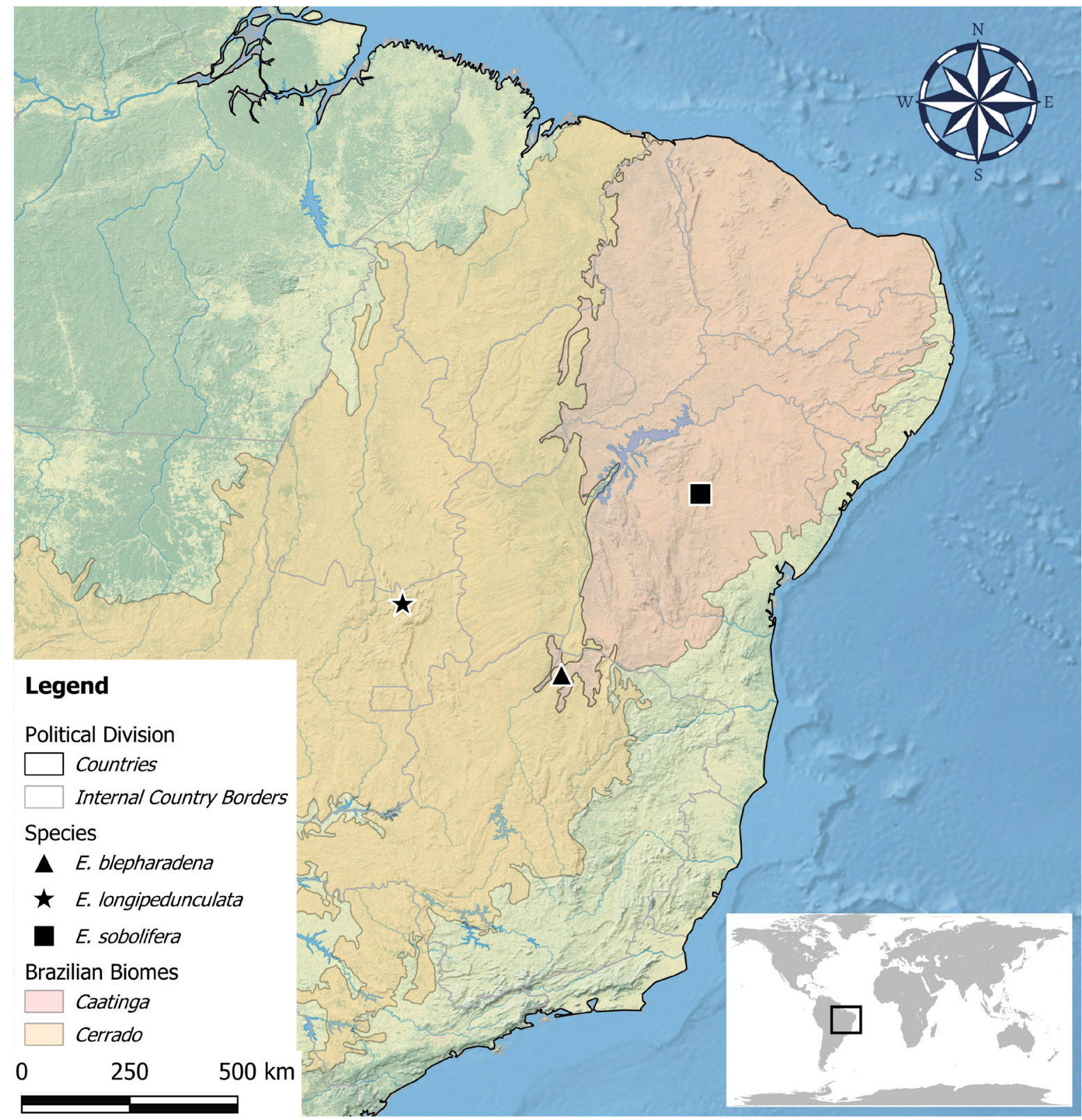

Fig. 2. Geographical distribution of Euphorbia blepharadena O.L.M.Silva \& Cordeiro sp. nov. (triangle), E. longipedunculata O.L.M.Silva \& Riina sp. nov. (star) and E. sobolifera O.L.M.Silva \& P.J.Braun sp. nov. (square). 
Euphorbia longipedunculata O.L.M.Silva \& Riina sp. nov. http://www.ipni.org/urn:1sid:ipni.org:names:77214814-1

Figs 2-3

\section{Diagnosis}

Euphorbia longipenduculata O.L.M.Silva \& Riina sp. nov. is most closely related to Euphorbia potentilloides Boiss., but differs in its orbicular leaves, long-pedunculate cyathia (5-10 mm long, reaching up to $45 \mathrm{~mm}$ long when the cyathium is fully developed) and longer cyathial gland appendages (ca $3 \times 4 \mathrm{~mm})$.

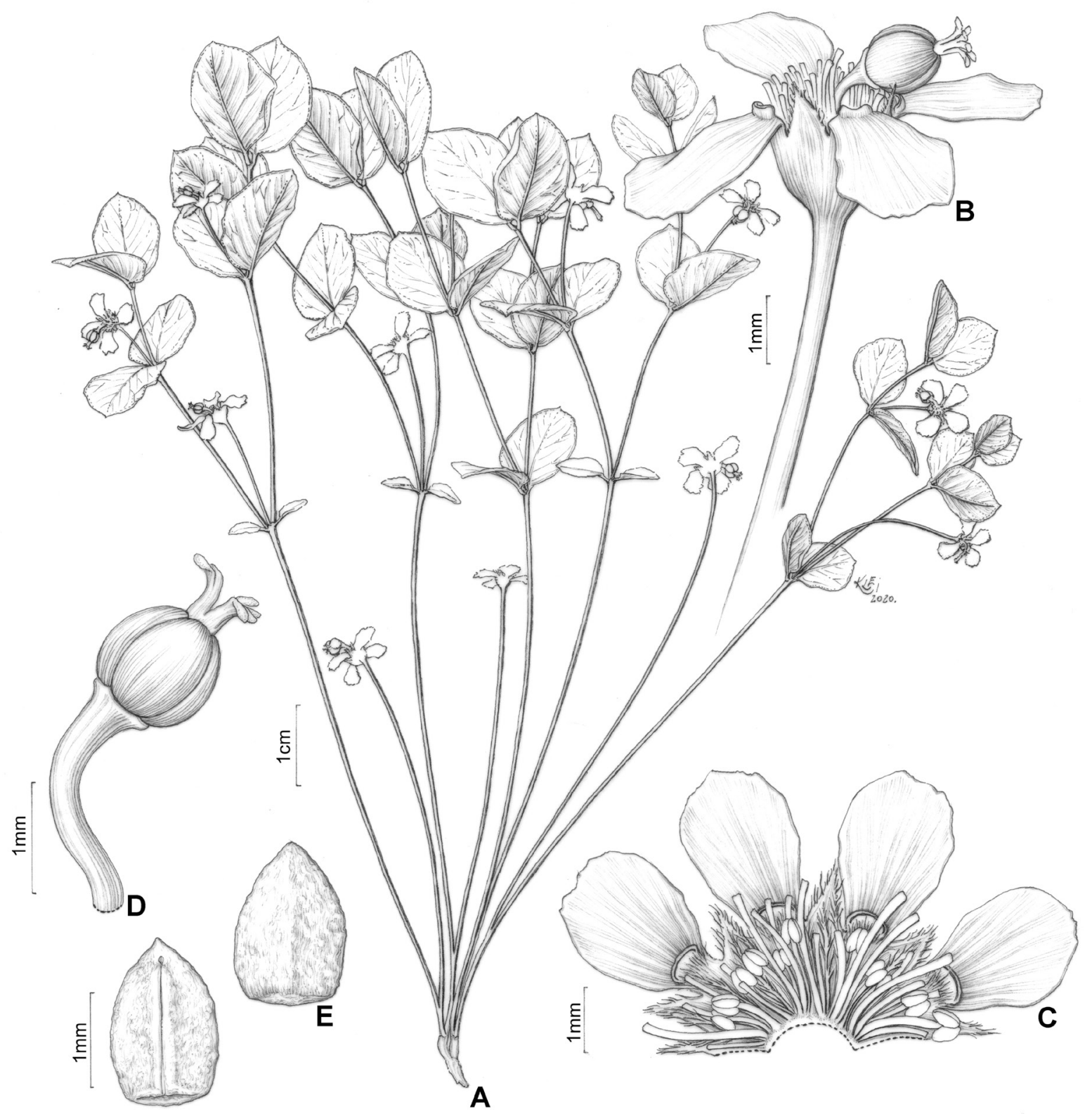

Fig. 3. Euphorbia longipedunculata O.L.M.Silva \& Riina sp. nov. A. Habit. B. Cyathium, C. Opened cyathium, showing staminate cymules and bracteoles, D. Young fruit. E. Seeds in ventral (left) and dorsal (right) views. Illustrations of the holotype, B.M.T. Walter et al. 4688 (SP), by Klei Souza. 
Type

BRAZIL • Goiás, Cavalcante, Estrada Minaçu - Cavalcante, "passando pela balsa Serra Branca, a cerca de $126 \mathrm{~km}$ do rio Tocantins" [after Serra Branca ferry, around $120 \mathrm{~km}$ from Tocantins river]; $13^{\circ} 35^{\prime} 35^{\prime \prime} \mathrm{S}$, 47³1'24" W; 1120 m a.s.1.; 10 Nov. 2000; B.M.T. Walter et al. 4688; holotype: SP[360090]; isotypes: CEN[CEN00041136], HUEFS[HUEFS000199840], SP[468419].

\section{Etymology}

The epithet is a reference to the long peduncle of the cyathium (Fig. 3A), which is remarkable among all species of Euphorbia in Brazil.

\section{Description}

Erect monoecious herbs, up to $20 \mathrm{~cm}$ tall; underground system probably xylopodiferous, unbranched; latex white. Stems terete, dichotomously branched from the base, slightly reddish when dried, glabrous. Leaves opposite, persistent, subsessile (petioles reaching up to $1.5 \mathrm{~mm}$ long); stipules interpetiolar, deltoid, inconspicuous (up to $1 \mathrm{~mm}$ long), apex with stiff short (up to $0.25 \mathrm{~mm}$ long) simple trichomes; leaf blade membranaceous, glabrous on both surfaces, discolorous (abaxial surface glaucous), orbicular, $(0.8-) 1-1.5(-1.7) \times(0.8-) 1-1.5(-1.7) \mathrm{cm}$, base obtuse to slightly truncate, margin entire, thickened, apex cuspidate, venation brochidodromous. Cyathia solitary at the axils of dichotomous branches, longpedunculate; peduncle 5-10 $\mathrm{mm}$ long (reaching up to $45 \mathrm{~mm}$ long when cyathium is fully developed), glabrous; cyathophylls similar to the leaves; involucre campanulate, 3-5 $\times 3-5 \mathrm{~mm}$, actinomorphic, glabrous on the outer surface; involucral lobes triangular, pale when dried, apex partite, glabrous; cyathial glands 4 or 5 , yellowish when dried, transversely elliptic, slightly concave, glabrous on both surfaces, $0.2-0.3 \times 0.5-1 \mathrm{~mm}$; cyathial gland appendages petaloid, wide-obovate, ca $3 \times 4 \mathrm{~mm}$, white when dried, glabrous on both surfaces, margin crenate, veins conspicuous. Staminate flowers 25(30), arranged in 5 cincinni with 5(6) flowers each; bracteoles lanceolate, ciliate; pedicels up to $2 \mathrm{~mm}$ long, filaments up to $1 \mathrm{~mm}$ long, anthers ca $1 \mathrm{~mm}$ wide, dorsifixed, extrorse, transversely dehiscent. Pistillate flowers ca $3.5 \mathrm{~mm}$ long; pedicel up to $2 \mathrm{~mm}$ long; ovary globose, ca $1 \times 1 \mathrm{~mm}$, glabrous; styles 3 , up to $0.5-0.8 \mathrm{~mm}$ long when fully developed, united only at the base, shortly bifid at the apex. Capsule 3-lobed, subglobose, 3-4.5 $\times 4-5 \mathrm{~mm}$, glabrous, pale when dried; pedicel shortly accrescent, reaching up to $5 \mathrm{~mm}$ long; columella ca $3 \mathrm{~mm}$ long; seeds brown, ovoid, $1.8-2.3 \times 1-1.2 \mathrm{~mm}$, rounded in cross section, testa slightly tuberculate; caruncle absent.

\section{Distribution, ecology, and phenology}

Euphorbia longipedunculata sp. nov. grows in open cerrado vegetation ('campo limpo') near the Chapada dos Veadeiros in northern Goiás, within the Cerrado domain (Fig. 2).

\section{Provisional conservation status}

Euphorbia longipedunculata sp. nov. is only known from a single location (Fig. 2), it has AOO $<10 \mathrm{~km}^{2}$ and $\mathrm{EOO}<100 \mathrm{~km}^{2}$. As this location is close to roadsides, it is subject to continuing decline in area, extent and quality due to the always growing anthropic pressure in Central Brazil. In the light of this, we suggest that this new species be classified as Critically Endangered (CR; B2ab[iii]).

Euphorbia sobolifera O.L.M.Silva \& P.J.Braun sp. nov. urn:lsid:ipni.org:names:77214815-1

Figs 2, 4

\section{Diagnosis}

Euphorbia sobolifera O.L.M.Silva \& P.J.Braun sp. nov. is similar to E. appariciana Rizzini, but differs in being dioecious, decumbent and having soboliferous growth, with stems reaching up to $2 \mathrm{~m}$ long. 
Type

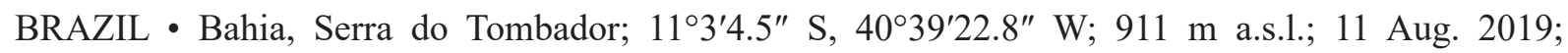
B.G. Brito 11; holotype: SP; isotypes: HUEFS, SPF, RB.

\section{Etymology}

The epithet refers to the soboliferous growth form of the species: when a stem becomes decumbent and reaches the soil, it starts branching and eventually roots. This allows $E$. sobolifera $\mathrm{sp}$. nov. to form dense colonies in the rocky outcrops where it grows (Fig. 4B).

\section{Description}

Decumbent dioecious shrubs, branches reaching up to $2 \mathrm{~m}$ long; underground system much branched; latex white. Stems slightly 6-costate, whorled branched, green to slightly reddish at the apex, glabrous, soboliferous. Leaves opposite, deciduous, subsessile (petioles reaching up to $1 \mathrm{~mm}$ long); stipules lateral and glanduliform, globose, inconspicuous (up to $1 \mathrm{~mm}$ long); leaf blade membranaceous, glabrous on both surfaces, concolorous, elliptic, narrow-elliptic or oblong, $(0.5-) 1-1.5(-2) \times 0.1-0.5 \mathrm{~cm}$, base attenuate, margin entire, apex cuspidate, venation hyphodromous. Cyathia solitary and sessile (pistillate) or glomerulate and subsessile (staminate), terminal; peduncle up to $1 \mathrm{~mm}$ long, glabrous; cyathophylls opposite, sessile, wide-elliptic to triangular, 1.0-1.5 $\times 0.5-0.8 \mathrm{~mm}$, with 2(3) pairs of lateral colleters at the base, chartaceous, glabrous on both surfaces, persistent, base truncate, margin entire, apex cuspidate, venation hyphodromous; involucre campanulate, 1.5-2.5 × 1.5-2.5 mm, actinomorphic, glabrous on the outer surface; involucral lobes triangular, pale to greenish, margin fimbriate, with simple trichomes; cyathial glands 5(6), yellow, transversely elliptic, punctate, glabrous, $0.5-1.0 \times 1.5-2.0(-2.5) \mathrm{mm}$; short crenulate white appendages. Staminate cyathia: staminate flowers 20-30, arranged in 5 cincinni with 4-6 flowers each; bracteoles lanceolate, ciliate; pedicels up to $1.0 \mathrm{~mm}$ long, filaments up to $0.5 \mathrm{~mm}$ long, anthers ca $1 \mathrm{~mm}$ wide, dorsifixed, extrorse, transversely dehiscent; pistillate flowers reduced to a pistillode, ca $0.5 \mathrm{~mm}$ long, with three inconspicuous styles that never exceed the involucre rim of the cyathia. Pistillate cyathia: staminate flowers atrophied and not exceeding involucre rim of the cyathia; pistillate flowers ca $2 \mathrm{~mm}$ long; pedicel up to $0.5 \mathrm{~mm}$ long; ovary globose, ca $0.5 \times 0.5 \mathrm{~mm}$, glabrous; styles 3, up to $1 \mathrm{~mm}$ long when fully developed, free at the base, bifid for half their length and revolute at the apex. Capsules 3-lobed, subglobose, 2-3 $\times 3-4 \mathrm{~mm}$ (immature), glabrous, green; pedicel shortly accrescent, reaching up to $2 \mathrm{~mm}$ long (immature fruit); columella and seeds not seen.

\section{Distribution, ecology and phenology}

Euphorbia sobolifera sp. nov. grows in open vegetation on sandstone outcrops (Fig. 4A) in the Serra do Tombador, near the Jacobina Municipality, in the northern portion of the Chapada Diamantina complex in Bahia State, within the Caatinga domain (Fig. 2). The species was collected during the dry season (August) with immature fruits, but individuals cultivated in the São Paulo Botanical Garden have been producing cyathia throughout the year, although we could not make them produce viable fruits.

\section{Provisional conservation status}

Euphorbia sobolifera sp. nov. is only known from a single locality (Fig. 2), with AOO $<10 \mathrm{~km}^{2}$ and $\mathrm{EOO}<100 \mathrm{~km}^{2}$, and its habitat is subjected to continuing decline in area, extent and quality. We suggest that it should be classified as Critically Endangered (CR; B2ab[iii]).

\section{Discussion}

Both Euphorbia blepharadena sp. nov. and E. longipedunculata sp. nov. are here placed in E. sect. Anisophyllum based on morphological characters, such as the presence of interpetiolar stipules and opposite leaves with the base asymmetrical (Yang et al. 2012). Euphorbia sobolifera sp. nov., in turn, 


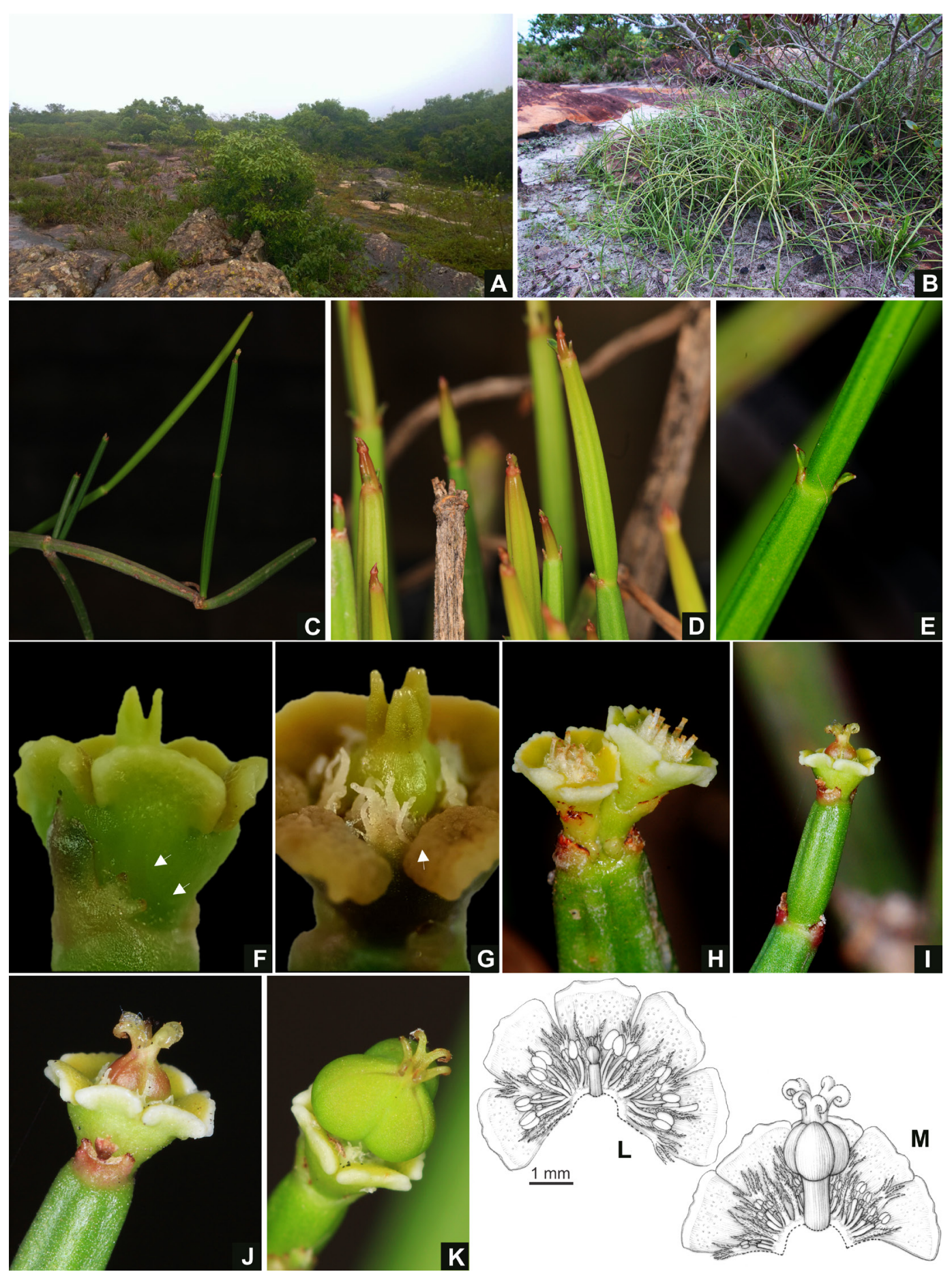

Fig. 4. Euphorbia sobolifera O.L.M.Silva \& P.J.Braun sp. nov. A. Habitat. B. Habit. C. Portion of a branch producing soboles. D. Apical portion of branches with reduced opposite leaves. E. Detail of a node with opposite leaves. F. Cyathium showing one of the cyathophylls bearing colleters on its margin (arrows). G. Detail of a cyathium showing an involucre lobe (arrow). H. Grouped staminate cyathia. I. Solitary pistillate cyathium. J. Detail of a pistillate cyathium showing the pistillate flower. K. Immature fruit. L. Staminate cyathium opened, showing staminate cymules, bracteoles and a central pistillode. M. Pistillate cyathium opened, showing poorly developed staminate flowers and bracteoles. Photos: A-B: P.J. Braun in the field; C-K: O.L.M. Silva; L-M: Illustrations of plants cultivated at the Instituto de Botânica by Klei Souza. 
is placed in E. sect. Crossadenia subsect. Apparicianae Riina by the combination of rudimentary and soon deciduous leaves (Fig. 4D-E) and cyathial glands with short crenulate appendages. (Fig. 4F-K; Yang et al. 2012).

Amongst the species of Euphorbia sect. Anisophyllum found in Brazil, E. blepharadena sp. nov. is most similar to E. foliolosa. due to its long and entire styles (Fig. 1H) and the presence of a colleter on the apex of leaf margin teeth (Fig. 1D; Silva et al. 2014). Euphorbia bahiensis (Klotzsch \& Garcke) Boiss. and E. hyssopifolia L. also share with E. blepharadena sp. nov. the herbaceous and erect habit with cyathia arranged in dichasia, but lack the features shared with $E$. foliolosa mentioned above (Silva et al. 2014). A more detailed comparison among E. bahiensis, E. blepharadena sp. nov., E. foliolosa and E. hyssopifolia is presented in Table 1 .

The cyathial glands bearing digitate appendages (Fig. 1G) present in Euphorbia blepharadena sp. nov. are only found in a few species of E. sect. Anisophyllum (e.g., E. hooveri Wheeler), none of them are found in Brazil (Yang et al. 2012). Nevertheless, among Brazilian Euphorbia, this type of appendage is found in some species of E. sects. Crossadenia (e.g., E. sarcodes Boiss. and E. adenoplicata O.L.M.Silva \& Cordeiro; Carneiro-Torres et al. 2012; Silva et al. 2020) and Alectoroctonum (Schltdl.) Baill. (E. sciadophila Boiss.; Silva et al. 2014).

Euphorbia longipedunculata sp. nov., the other new species placed in E. sect. Anisophyllum, was hidden in numerous herbaria collections under the common E. potentilloides, which is widely distributed across the Cerrado domain (Simmons \& Hayden 1997). This was most probably due to the superficial resemblance of these species, especially considering the plasticity in leaf shape of E. potentilloides as described by Simons \& Hayden (1997). Despite the high variability in leaf shape (Simons \& Hayden 1997: fig. 17), E. potentilloides is not known to possess orbicular leaves as in E. longipedunculata sp. nov. (Fig. 3A). In E. potentilloides, the cyathia are arranged in pleiochasia and sit upon a peduncle that reaches up to $1.6 \mathrm{~mm}$ long (or rarely $12 \mathrm{~mm}$ ) (Simons \& Hayden 1997), whereas in E. longipedunculata sp. nov. they are solitary in the axils of dichotomous branches and, when young, the peduncle is $5-10 \mathrm{~mm}$ long, but reaches up to $45 \mathrm{~mm}$ long when mature (Fig. 3A-B). Nevertheless, cyathial glands appendages are conspicuously larger in E. longipedunculata sp. nov. (ca $3 \times 4 \mathrm{~mm}$; Fig. 3C) than in E. potentilloides (0.1-1(-2.1) mm long; Simons \& Hayden 1997).

Another species that is also similar to Euphorbia potentilloides is E. burchellii Müll.Arg (Müller Argoviensis 1874). However, E. burchellii is only known from the type and rarely would be confused with E. longipedunculata sp. nov., due to its lanceolate to linear leaves (vs rounded in E. longipedunculata sp. nov.). A comprehensive comparison among these three species is given in Table 2.

Within Euphorbia sect. Crossadenia, the third newly described species, E. sobolifera sp. nov., is most similar to E. appariciana due to its 6-costate stems with short internodes (Fig. 4C-E) and unisexual cyathia (Fig. 4F-M) but differs from the latter by being dioecious (vs monoecious in E. appariciana) and presenting more conspicuous and opposite leaves (Fig. 4E), while in E. appariciana, the leaves are completely absent or very rudimentary (Rizzini 1989). Additionally, E. sobolifera sp. nov. has longer and thinner stems that reach up to $2 \mathrm{~m}$ long, becoming decumbent (Fig. 4B), whereas in E. appariciana, stems are thicker, always erect and they usually reach up to $20 \mathrm{~cm}$ tall. Slender decumbent branches are also present in E. teres M.Machado \& Hofacker, but the latter has terete stems (vs 6-costate stems in E. sobolifera sp. nov.; Fig. 4E). Finally, Euphorbia flaviana Carn.-Torres \& Cordeiro also has terete stems, but these are always erect, reaching more than $1 \mathrm{~m}$ high, and its cyathial glands are similar to those of E. sobolifera sp. nov., but they lack an appendage (vs short crenulate appendage in E. sobolifera sp. nov.). A morphological comparison of the new species with the others mentioned above is given in Table 3. 
Table 1. Morphological comparison among Euphorbia bahiensis (Klotzsch \& Garcke) Boiss., E. blepharadena O.L.M.Silva \& Cordeiro sp. nov., E. foliolosa Boiss. and E. hyssopifolia L.

\begin{tabular}{|c|c|c|c|c|}
\hline & E. bahiensis & $\begin{array}{c}\begin{array}{c}\text { E. blepharadena } \\
\text { sp. nov. }\end{array} \\
\end{array}$ & E. foliolosa & E. hyssopifolia \\
\hline $\begin{array}{c}\text { Stem } \\
\text { indumentum }\end{array}$ & glabrous & $\begin{array}{l}\text { pubescent,with short } \\
(<0.25 \mathrm{~mm}) \text { curved } \\
\text { and longer (ca } 1 \mathrm{~mm}) \\
\text { erect simple trichomes }\end{array}$ & $\begin{array}{l}\text { pubescent, with short } \\
(<0.5 \mathrm{~mm} \text { long }) \\
\text { curved or erect simple } \\
\text { trichomes }\end{array}$ & $\begin{array}{c}\text { glabrous or pilose } \\
\text { to pubescent, with } \\
\text { short }(<0.5 \mathrm{~mm} \text { long }) \\
\text { curved or erect simple } \\
\text { trichomes }\end{array}$ \\
\hline Leaf margin & $\begin{array}{c}\text { entire to } \\
\text { inconspicuously } \\
\text { serrate, without a } \\
\text { colleter on the apex } \\
\text { of each tooth }\end{array}$ & $\begin{array}{l}\text { serrate, with a colleter } \\
\text { on the apex of each } \\
\text { tooth }\end{array}$ & $\begin{array}{l}\text { serrate, with a colleter } \\
\text { on the apex of each } \\
\text { tooth }\end{array}$ & $\begin{array}{l}\text { serrate, without a } \\
\text { colleter on the apex of } \\
\text { each tooth }\end{array}$ \\
\hline Leaf venation & actinodromous & hyphodromous & actinodromous & actinodromous \\
\hline $\begin{array}{c}\text { Leaf } \\
\text { indumentum }\end{array}$ & glabrous & $\begin{array}{l}\text { pilose on the adaxial } \\
\text { surface and densely } \\
\text { pilose on the abaxial } \\
\text { surface, both surfaces } \\
\text { with long (ca } 1 \mathrm{~mm} \text { ) } \\
\text { erect simple trichomes }\end{array}$ & $\begin{array}{l}\text { pilose on the adaxial } \\
\text { surface and densely } \\
\text { pilose on the abaxial } \\
\text { surface, both surfaces } \\
\text { with short }(<0.5 \mathrm{~mm} \\
\text { long) curved or erect } \\
\text { simple trichomes }\end{array}$ & $\begin{array}{l}\text { glabrous or with a } \\
\text { few scattered short } \\
(<0.5 \mathrm{~mm} \text { long }) \\
\text { curved or erect simple } \\
\text { trichomes }\end{array}$ \\
\hline $\begin{array}{c}\text { Cyathia } \\
\text { arrangement }\end{array}$ & $\begin{array}{l}\text { in dichasia, with } \\
\text { lateral axis not } \\
\text { congested }\end{array}$ & solitary & $\begin{array}{l}\text { solitary or in dichasia, } \\
\text { with lateral axis not } \\
\text { congested }\end{array}$ & $\begin{array}{l}\text { in dichasia, with } \\
\text { lateral axis congested }\end{array}$ \\
\hline $\begin{array}{l}\text { Cyathial glands } \\
\text { appendages }\end{array}$ & petaloid & 6-8-digitate & petaloid & petaloid \\
\hline $\begin{array}{l}\text { Ovary/fruit } \\
\text { indumentum }\end{array}$ & glabrous & $\begin{array}{l}\text { densely pubescent/ } \\
\text { pubescent with long } \\
\text { (ca } 1 \mathrm{~mm} \text { ) erect } \\
\text { simple trichomes }\end{array}$ & glabrous & glabrous \\
\hline Styles & $\begin{array}{l}\text { short (up to } 0.5 \mathrm{~mm} \text { ) } \\
\text { and bifid half of } \\
\text { their length }\end{array}$ & $\begin{array}{c}\text { long (ca } 2 \mathrm{~mm} \text { ) and } \\
\text { entire }\end{array}$ & $\begin{array}{c}\text { long }(3.5-4 \mathrm{~mm}) \text { and } \\
\text { entire }\end{array}$ & $\begin{array}{l}\text { short (up to } 0.8 \mathrm{~mm} \text { ) } \\
\text { and bifid half of their } \\
\text { length }\end{array}$ \\
\hline
\end{tabular}

The dioecy of Euphorbia sobolifera sp. nov. was confirmed through the observation in cultivation of three distinct individuals. These were collected by B.G. Brito in the type locality and sent to São Paulo for cultivation at the São Paulo Botanical Garden (two individuals of different sexes) and also at the Botany Department at the University of São Paulo (one male individual). Individuals of different sexes were growing together in the São Paulo Botanical Garden and we have been observing them for around one year while one consistently produced staminate cyathia and the other pistillate ones. However, a single fruit was observed in an individual at São Paulo Botanical Garden (Fig. 4K), that unfortunately did not reach maturity. Therefore, fruits and seeds are missing in the description and type specimen of E. sobolifera sp. nov., because we were unable to cross the individuals to produce more viable fruits. Branches from both male and female individuals collected by B.G. Brito were gathered to compose a single herbarium sheet to better represent the species in the holotype in accordance with article 8.2 of the International Code of Nomenclature for Algae, Fungi and Plants (Turland et al. 2018). Although 
Table 2. Morphological comparison among Euphorbia burchelli Müll.Arg., E. longipedunculata O.L.M.Silva \& Riina sp. nov. and E. potentilloides Boiss.

\begin{tabular}{cccc}
\hline & E. burchelli & $\begin{array}{c}\text { E. longipedunculata } \\
\text { sp. nov. }\end{array}$ & E. potentilloides \\
\hline Leaf shape & lanceolate to linear & orbicular & $\begin{array}{c}\text { ovate to oblong or lanceolate } \\
\text { to linear }\end{array}$ \\
$\begin{array}{c}\text { Cyathia } \\
\text { arrangement }\end{array}$ & solitary & solitary & $\begin{array}{c}\text { in pleiochasia (with posterior } \\
\text { dichasial branching) }\end{array}$ \\
$\begin{array}{c}\text { Length (mm) of } \\
\text { cyathium peduncle } \\
\begin{array}{c}\text { Length (mm) of } \\
\text { cyathial gland } \\
\text { appendages }\end{array}\end{array}$ & up to 5 & $\begin{array}{c}5-10 \text { (when young) } \\
\text { up to } 1.6(-12)\end{array}$ \\
\hline
\end{tabular}

Table 3. Morphological comparison among E. appariciana Rizzini, E. flaviana Carn.-Torres \& Cordeiro, E. sobolifera O.L.M.Silva \& P.J.Braun sp. nov. and E. teres M.Machado \& Hofacker.

\begin{tabular}{ccccc}
\hline & E. appariciana & E. flaviana & $\begin{array}{c}\text { E. sobolifera } \\
\text { sp. nov. }\end{array}$ & E. teres \\
\hline $\begin{array}{c}\text { Sexual system } \\
\text { Plant stature }\end{array}$ & monoecious & monoecious & dioecious & monoecious \\
and disposition & high to $20 \mathrm{~cm}$ & $\begin{array}{c}\text { erect, } 80-150 \mathrm{~cm} \\
\text { high }\end{array}$ & $\begin{array}{c}\text { decumbent, } \\
\text { branches } \\
\text { reaching up to } \\
\text { erect or decumbent, up to }\end{array}$ & $\begin{array}{c}50 \mathrm{~cm} \text { high or decumbent } \\
\text { branches reaching up to } \\
70 \mathrm{~m} \text { long }\end{array}$ \\
$\begin{array}{c}\text { Stem cross } \\
\text { section }\end{array}$ & 6-costate & rounded & 6-costate & rounded \\
$\begin{array}{c}\text { Cyathia } \\
\begin{array}{c}\text { Outer margin } \\
\text { of cyathial } \\
\text { glands }\end{array}\end{array}$ & unisexual & bisexual & unisexual & bisexual \\
dentate & entire & dentate & dentate \\
\hline
\end{tabular}

seeds could not be observed in this species, representatives of Euphorbia sect. Crossadenia have highly conserved seed features (seed coat with low and rounded tubercles and the presence of a caruncle-like feature but without an elaiosome) that may be synapomorphic to the group (Yang et al. 2012; Silva et al. 2020).

In conclusion, the three new species presented in this work represent important additions to the Euphorbiaceae in the Flora of Brazil 2020 project, increasing the number of species of Euphorbia in Brazil to 67. These new species also show interesting uncommon features among the Brazilian species: the dioecy and soboliferous growth form of E. sobolifera sp. nov., the long pedunculate cyathia of E. longipedunculata sp. nov., and the digitate cyathial glands of E. blepharadena sp. nov., which is rare in E. sect. Anisophyllum. Although these species are only known from their types, descriptions of taxa from single collections are important for conservation and enhancement of sampling efforts in underexplored areas of the Neotropics (Wood et al. 2017; Antar et al. 2018; Riina et al. 2018; Silva et al. 2020). 


\section{Acknowledgements}

We thank the curators of all the herbaria cited in this work for providing access to their collections. We are grateful to FAPESP for the scholarship awarded to the first author (FAPESP process number 2019/09237-0) and the financial support for I. Cordeiro (CNPq process number 309917/2015-8); to the two anonymous reviewers for their contributions to early versions of the manuscript; to Klei Souza for producing the illustrations presented in this work; and to B.G. Brito for collecting and sending samples of Euphorbia sobolifera sp. nov. for the elaboration of this manuscript.

\section{References}

Antar G.M., Santos M.F. \& Sano P.T. 2018. Rediscovery and taxonomic reassessment of four angiosperms in the savannas of Jalapão, Central Brazil. Edinburgh Journal of Botany 75: 181-195. https://doi.org/10.1017/S0960428617000348

Beentje H. 2010. The Kew Plant Glossary - an Illustrated Dictionary of Plant Terms. Kew Publishing, Kew.

Carneiro-Torres D.S., Cordeiro I., Giulietti A.M. \& Riina R. 2012. Euphorbia flaviana, a new species from the inselbergs of Bahia (Brazil) and lectotypification of E. crossadenia. Systematic Botany 37: 688-693. https://doi.org/10.1600/036364412X648652

Carrillo-Reyes P. \& Steinmann V.W. 2011. Two new species of Euphorbia sect. Nummulariopsis (Euphorbiaceae) from South America. Anales del Jardin Botánico de Madrid 68: 167-173.

https://doi.org/10.3989/ajbm.2282

Dorsey B.L., Haevermans T., Aubriot X., Morawetz J.J., Riina R., Steinmann V.W. \& Berry P.E. 2013. Phylogenetics, morphological evolution, and classification of Euphorbia subgenus Euphorbia. Taxon 62: 291-315. https://doi.org/10.12705/622.1

Flora do Brasil. 2020 (in construction). Euphorbia. Jardim Botânico do Rio de Janeiro. Available from: http://floradobrasil.jbrj.gov.br/reflora/floradobrasil/FB17561 [accessed 15 Aug. 2020].

Govaerts R., Frodin D.G. \& Radcliffe-Smith A. 2000. World Checklist and Bibliography of Euphorbiaceae (and Pandaceae) 2. Kew Publishing, Kew.

Horn J.W., van Ee B.W., Morawetz J.J., Riina R., Steinmann V.W., Berry P.E. \& Wurdack K.J. 2012. Phylogenetics and the evolution of major structural characters in the giant genus Euphorbia L. (Euphorbiaceae). Molecular Phylogenetics and Evolution 63: 305-326.

https://doi.org/10.1016/j.ympev.2011.12.022

Hurbath F., Leal B.S.S., Silva O.L.M., Palma-Silva C. \& Cordeiro I. 2018. A new species and molecular phylogeny of Brazilian succulent Euphorbia sect. Brasilienses. Systematics and Biodiversity 16: 658667. https://doi.org/10.1080/14772000.2018.1473897

IUCN Standards and Petitions Committee. 2019. Guidelines for Using the IUCN Red List Categories and Criteria, ver. 14. Prepared by the Standards and Petitions Subcommittee of the IUCN Species Survival Commision. Available from

https://nc.iucnredlist.org/redlist/content/attachment_files/RedListGuidelines.pdf [accessed 29 Feb. 2020].

Küllkamp J., Silva O.L.M., Valduga E., Iganci J.R.V., Cordeiro I. \& Baumgratz J.F.A. 2018. First record of Euphorbia pedersenii Subils (Euphorbiaceae) for Brazil. Phytotaxa 379: 287-292.

https://doi.org/10.11646/phytotaxa.379.4.2

Müller Argoviensis J. 1874. Euphorbiaceae. In: Martius C.F.P. von \& Eichler A.W. (eds) Flora Brasiliensis 11 (2). Frid. Fleischer, München. 
Peirson J.A., Bruyns P.V., Riina R., Morawetz J.J. \& Berry P.E. 2013. A molecular phylogeny and classification of the largely succulent and mainly African Euphorbia subg. Athymalus (Euphorbiaceae). Taxon 62: 1178-1199. https://doi.org/10.12705/626.12

Prenner G., \& Rudall P.J. 2007. Comparative ontogeny of the cyathium in Euphorbia (Euphorbiaceae) and its allies: exploring the organ, flower, inflorescence boundary. American Journal of Botany 94: 1612-1629. https://doi.org/10.3732/ajb.94.10.1612

QGIS Development Team. 2020. QGIS Geographic Information System. Open Source Geospatial Foundation Project. Available from http://qgis.osgeo.org [accessed 29 Feb. 2020].

Radcliffe-Smith A. 2001. Genera Euphorbiacearum. Kew Publishing, Kew.

Riina R., Peirson J.A., Geltman D.V., Molero J., Frajman B., Pahlevani A., Barres L., Morawetz J.J., Salmaki Y., Zarre S., Kryukov A., Bruyns P.V. \& Berry P.E. 2013. A worldwide molecular phylogeny and classification of the leafy spurges, Euphorbia subgenus Esula (Euphorbiaceae). Taxon 62: 316-342. https://doi.org/10.12705/622.3

Riina R., Berry P.E., Secco R.S., Meier W. \& Caruzo M.B.R. 2018. Reassessment of Croton sect. Cleodora (Euphorbiaceae) points to the Amazon Basin as its main center of diversity. Annals of the Missouri Botanical Garden 103: 330-349. https://doi.org/10.3417/2018131

Rizzini C.T. 1989. Cactiform species of Euphorbia from Brazil (Euphorbiaceae). Revista Brasileira de Biologia 49: 979-997.

Silva O.L.M. \& Cordeiro I. 2015. Euphorbia sarcoceras, a new species of Euphorbia sect. Alectoroctonum from Brazil. Systematic Botany 40: 962-967. https://doi.org/10.1600/036364415X690003

Silva O.L.M., Cordeiro I. \& Caruzo M.B.R. 2014. Synopsis of Euphorbia (Euphorbiaceae) in the state of São Paulo, Brazil. Phytotaxa 181: 193-215. https://doi.org/10.11646/phytotaxa.181.4.1

Silva O.L.M., Antar G.M, Riina R. \& Cordeiro I. 2020. Euphorbia adenoplicata, a new species of Euphorbia sect. Crossadenia from Brazil. Systematic Botany 45: 131-136.

https://doi.org/10.1600/036364420X15801369352388

Simmons M.P. \& Hayden W.J. 1997. Revision of the cerrado hemicryptophytic Chamaesyce of Boissier's "Pleiadeniae" (Euphorbiaceae). Brittonia 49: 155-180. https://doi.org/10.2307/2807678

Steinmann V.W. 2013. Three new species of Euphorbia subg. Chamaesyce (Euphorbiaceae) from Bolivia. Phytotaxa 114: 23-32. https://doi.org/10.11646/phytotaxa.114.1.2

Thiers B. continuously updated. Index Herbariorum: A Global Directory of Public Herbaria and Associated Staff. The New York Botanical Garden, New York.

Available from http://sweetgum.nybg.org/ih/ [accessed 15 Aug. 2020].

Turland N.J., Wiersema J.H., Barrie F.R., Greuter W., Hawksworth D.L., Herendeen P.S., Knapp S., Kusber W., Li D., Marhold K., May T.W., McNeill J., Monro A.M., Prado J., Price M. \& Smith G.F. 2018. International Code of Nomenclature for Algae, Fungi, and Plants (Shenzhen Code) Adopted by the Nineteenth International Botanical Congress Shenzhen, China, July 2017. Koeltz Scientific Books, Königstein.

Webster G.L. 2014. Euphorbiaceae. In: Kubitzki K. (ed.) The Families and Genera of Vascular Plants 11: 51-216. Springer Verlag, Berlin \& Heidelberg. https://doi.org/10.1007/978-3-642-39417-1_10

Wood J.R.I., Muñoz-Rodriguez P., Degen R. \& Scotland R.W. 2017. New species of Ipomea (Convolvulaceae) from South America. PhytoKeys 88: 1-38.

https://doi.org/10.3897/phytokeys.88.12891 
Yang Y., Riina R., Morawetz J.J., Haevermans T., Aubriot X. \& Berry P.E. 2012. Molecular phylogenetics and classification of Euphorbia subgenus Chamaesyce (Euphorbiaceae). Taxon 61: 764-789. https://doi.org/10.1002/tax.614005

Manuscript received: 8 September 2020

Manuscript accepted: 16 November 2020

Published on: 3 February 2021

Topic editor: Frederik Leliaert

Desk editor: Radka Rosenbaumová

Printed versions of all papers are also deposited in the libraries of the institutes that are members of the EJT consortium: Muséum national d'histoire naturelle, Paris, France; Meise Botanic Garden, Belgium; Royal Museum for Central Africa, Tervuren, Belgium; Royal Belgian Institute of Natural Sciences, Brussels, Belgium; Natural History Museum of Denmark, Copenhagen, Denmark; Naturalis Biodiversity Center, Leiden, the Netherlands; Museo Nacional de Ciencias Naturales-CSIC, Madrid, Spain; Real Jardín Botánico de Madrid CSIC, Spain; Zoological Research Museum Alexander Koenig, Bonn, Germany; National Museum, Prague, Czech Republic. 